\title{
IAMJ
}

INTERNATIONAL

AYURVEDIC

MEDICAL JOURNAL

\section{NON-ALCOHOLIC FATTY LIVER DISEASE - AN AYURVEDIC VIEW}

\section{$\underline{\text { Aparna Chandran }}^{1}, \underline{\text { L. Mahadevan }}{ }^{2}, \underline{\text { Nisha M.G }}^{3}, \underline{\text { Arun Pratap }}^{4}$}

${ }^{1}$ Final year PG Scholar, Dept of Kayachikitsa, Pankajakasthuri Ayurveda Medical College \& PG Centre

${ }^{2}$ Professor, Dept of Kayachikitsa, Pankajakasthuri Ayurveda Medical College \& PG Centre

${ }^{3}$ Assistant Professor, Dept of Roga Nidanam, Pankajakasthuri Ayurveda Medical College \& PG Centre

${ }^{4}$ Professor, Dept of Kayachikitsa, Pankajakasthuri Ayurveda Medical College \& PG Centre

\section{Corresponding Author: aparnabs94@gmail.com}

\section{https://doi.org/10.46607/iamj2409112021}

(Published Online: November 2021)

Open Access

(C) International Ayurvedic Medical Journal, India

Article Received: 17/10//2021 - Peer Reviewed: 30/10/2021 - Accepted for Publication: 31/10/2021

\section{Check for updates}

\begin{abstract}
Non-Alcoholic Fatty Liver Disease (NAFLD) is a distinct hepatic condition characterized by abnormal fat accumulation in liver cells and histologically it resembles alcohol-induced liver damage. The prevalence of NAFLD is up to $30 \%$ in developed countries and $10 \%$ in developing nations, making NAFLD the most common liver condition in the world. The liver can be compared with Yakrit (Liver) mentioned in Ayurvedic classics as an important Koshtanga (organ of the gastrointestinal system). But NAFLD as such could not be correlated to any of the Yakrit Rogas (Liver disorders) mentioned in Ayurvedic classics. Understanding the Nidana (aetiology) and Samprapti (pathogenesis) of the disease, NAFLD can be considered as a Santarpanajanya Vyadhi (disease due to over nourishment). Here initially Agnivikruti (deranged digestive fire) occurs which leads to the formation of Ama (Free radicals) which results from the vitiation of Kaphadosha and further results in unequal formation and deposition of Dushta Vasa (triglycerides) in Yakrit. Hence Agnideepana (stimulating digestive fire), Amapachana (antioxidation), Lekhana (scraping), Srotosodhana (clearing of channels of circulation), Kapha Medohara (antihyperlipidemic) and Vataanulomana (normalising the movement of Vata) is aimed primarily in the management of NAFLD
\end{abstract}

Keywords: Non-Alcoholic Fatty Liver Disease, Ultrasonography, Liver Function Test, Santarpanajanya Vyadhi 


\section{INTRODUCTION}

Non-alcoholic fatty liver disease (NAFLD) is defined by macrovesicular steatosis in $\geq 5 \%$ hepatocytes, in the absence of a secondary cause such as alcohol or drugs. It is characterized by steatosis of the liver, involving greater than $5 \%$ of parenchyma, with no evidence of hepatocyte injury. The incidence of NAFLD is estimated to be 5\%-18\% in Asia ${ }^{1}$. In India, the prevalence of NAFLD is around $9 \%$ to $32 \%$ of the general population $^{2}$. NAFLD has been projected, within the next 20 years, to become the major cause of liver-related morbidity and mortality as well as a leading indication for liver transplantation ${ }^{3}$. Hence it is necessary to find proper management for the emerging disease. A direct reference of liver disease induced by impaired lipid metabolism due to sedentary lifestyle and improper dietary habits are not seen in Ayurvedic classics. Therefore, while understanding such diseases through Ayurveda, we must consider the Nidana, Dosha and Dooshya involved in the disease progression and thus NAFLD can be considered under the Santarpanajanya vyadhi explained by Acharya Caraka, in Sutrastana of Caraka samhitha.

\section{MATERIALS AND METHODS}

Ayurvedic classics, clinical medicine texts and related websites were referred to and reviewed for the present work.

\section{Disease Review}

Non-Alcoholic fatty liver disease (NAFLD) is a condition defined by excessive fat $(>5-10 \%$ of liver weight) accumulation in the form of triglycerides (steatosis) in the liver in the absence of any secondary cause like alcohol or drug use. The exact aetiology of the disease is still unknown. Insulin resistance, obesity, metabolic syndrome, oxidative stress and dietary factors are associated with the development of $\mathrm{NAFLD}^{4}$. Genetic factors and environmental factors also contribute to the development and progression of NAFLD. A two-hit hypothesis was proposed by Day and James. The first hit is caused by insulin resistance, which leads to the accumulation of fat droplets that is a triglyceride in the cytoplasm of hepatocytes leading to the development of steatosis. NAFLD impairs glu- cose and lipid metabolism by two mechanisms- by acting as an endocrine organ, which is releasing several fat-derived cytokines and by free fatty acid-induced ectopic fat deposition and lipotoxicity. The second hit is multifactorial, causing hepatocellular injury and the development of $\mathrm{NASH}^{5}$. The most common symptoms in NAFLD are Fatigue, right upper quadrant discomfort, Anorexia, Disturbed sleep patterns, Lethargy, Malaise $^{6}$. The main complication of Non-Alcoholic fatty liver disease is cirrhosis, which is late-stage scarring (fibrosis) in the liver ${ }^{7}$.

Acharya has listed 19 manifestations ranging from Pramehapitaka to Sopha under the Santarpana janya vyadhi and he has also stated that it can also lead to some other diseases with similar kinds of manifestations. The word Santarpana has originated from the root word - 'Trip preenane' which means to please, to nourish etc. Santarpanam is Samyak tarpana that is to cause extreme nourishment ${ }^{8}$. Therefore, Santarpana janya vyadhis can be considered as diseases that are caused due to over nourishment.

Nidana (aetiology) plays a significant role in the development as well as in the treatment of the disease. The various Aharaja (dietic) and Viharaja (regimental) factors involved here are Snigdha (unctuous), Madhura(sweet), Guru (heavy), Pichila (slimy) Ahara, Navanna, Anupa, Varija mamsa (meat of animal inhabiting arid and aquatic region), Goudika, Paishtika Annam, Cheshta dwesham, Divaswapnam, saiyya dosha etc ${ }^{8}$. Excessive intake of Ahara which are Guru, Snigdha, Sita, Pichilla and Madhurarasa produces Lepana (anointment) and Brimhana (heaviness), Tarpana (over nourishment) to Sareera (body) and thus leads to Kapha Dushti ${ }^{9}$. The intake of Dadhi (curd), Navadhanya (newly harvested grains) and Ksheera (milk) in excess can produce Srotorodha (obstruction to channels of circulation) due to their $A b$ hishyandi and Kledana property ${ }^{10}$. The Vihara mentioned here when followed for a longer duration can lead to vitiation of Kapha Dosha which subsequently results in the formation of Ama (free radicals). These Nidanas can be correlated with the present-day use of fried and oily food, butter, cheese, ghee etc. which are 
examples of Snigdha Ahara. Ati Madhura Aharas can include white sugars, pastries, sweet beverages, bakery products like halva, candies, cake. Pizzas, parottas, burgers etc. are Guru Aharas while Pichila Aharas include curd, fish etc.

Dosha in NAFLD: Even though the disease initiates with Kapha predominance, gradually the other two Doshas also get involved. Vata: Vata vitiation occurs here because of obstruction in the Srotas (channel of circulation) which is caused by the excessively vitiated Kapha and Ama (free radicals). As a result, there is Vata aggravation in Koshta. Pitta: by the continuous usage of Snigdha Ahara and Vihara Pitta dosha also gets affected (Pitta has Ishat snigdha guna). As the Samprapti (pathogenesis) happens in Yakrit (liver) which is the Raktavaha srotomula, due to the Asraya Asrayibhava of Rakta Dhatu and Pitta Dosha, Pitta is also found to be vitiated.

Dhatudushti and Srotodushti in NAFLD

Rasadhatu, Mamsadhatu and Medodhatu get vitiated by Kapha vitiation due to Asraya-asrayibhava. Apart from that, the Nidanas causes Agnimandya (deranged digestive fire) and thus result in the formation of improper Rasadhatu. As the Agnimandya persist and the person continues with the Nidana, the Utharothara Dhatu (successive tissue elements) formation gets affected. As a result, the Rakta Dhatu, Mamsa Dhatu and Medo Dhatu also gets affected. The vitiation of Dhatu, in turn, vitiates the Srotas and vice versa. Therefore, the respective Srotas also gets affected.

Agni in NAFLD

Due to Kaphapradhana Tridosha kopa, Jataragni mandya occurs. Due to the Jataragnimandya, there will be impairment of Bhootagni and respective Dhatwagni.

Samprapti

Due to Aharaja and Viharaja Nidanasevana, Kaphapradhana tridoshadosha kopa occurs in the body. This leads to Jataragnimandya and Ama formation. The formed Rasa Dhatu is in Dhooshita condition $^{11}$. This Rasa reaches Yakrit through Rasavaha srotas with the help of Vyana Vata. From the Amayukta Rasa, Amayukta Rakta is formed and the carrier of Dhooshita Rasa i.e., the Vyana Vata also gets vitiated. From the Dhooshita rakta, Dooshita mamsa is formed. Therefore, from the Dushtamamsa, Dushtavasa (triglycerides), which is the Sudhamamsasya Sneha is formed, and it gets located in the Yakrit. Yakrit is the Raktavaha Srotomula, due to the Asraya Asrayibhava of Rakta and Pitta, Pitta is also found to be vitiated ${ }^{13}$.

\section{LAKSHANA}

The specific Lakshanas of the disease is not mentioned separately. Since Jataragnimandya, Ama, Rasa, Rakta, Mamsa Medo Dhatu Dushti and Srotodushti occurs in the pathogenesis, features like Sadam, (Malaise) Tandra (Fatigue) Glani (Sleepiness) Alasya (Lethargy), Aruchi (Anorexia), Hrit daha (heartburn), Amlodgara (Sour belching) Anannabhilasha (Loss of appetite), Marutamoodata (Belching, Flatulence), Gaurava (Feeling of heaviness), Ati Kshudha (Excessive hunger), Daurbalya (General debility) can be present. Since Yakrit is affected, Symptoms from Pandu, Kamala and Udara like Ayasa Akshamata (Unable to bear physical exercise), Koshta sula (Right upper quadrant discomfort), Vishtambha (Distension of abdomen), Udaravriddhi (Enlargement of Abdomen) wiil be seen. ${ }^{14}$

UPADRAVA

If left untreated, it can progress to Kamala (Jaundice) and Udara (ascites) like conditions.

TREATMENT ${ }^{15,16}$

Since NAFLD is considered as a Santarpanajanya vyadhi, Apatarpana Chikitsa (non-nourishing treatment) must be adopted here.

Vamanam(emesis), Virechanam(purgation), Rakthamokshanam (bloodletting), Vyayamam(exercise), Upavasam(fasting), Dhoomapanam (medicated smoke), Swedanam and Choornapradeha are said by Acharya Caraka as therapeutic procedures in Santarpanajanya vyadhi.

Treatment here must aim at bringing back the normalcy of vitiated Doshas, along with the removal of causative factors. Agnivaigunya (deranged digestive fire), Kapha Medo Dushti at Mulasthana (root) of Raktavaha Srotas, Srotorodha and Vatakopa (provoked Vata) are involved in the pathogenesis of the 
disease. Therefore, the treatment should aim at $A g$ nideepana (stimulating digestive fire), Amapachana, Kapha Medo Anilapaha and Srotoshodhana (clearing the channels of circulation), which are almost similar to the treatment principle of Medoroga (Dyslipidemia). Dosha is in a Madhyama bala (moderate strength) stage, which should be treated by Langhana (fasting) and Pachana. Laghu (Light), Ushna (Hot) and Teekshna (Sharp) Dravya (drugs) can attain this. The drugs suitable here are Katu (pungent), Tiktha (bitter), Kashaya (astringent) Rasapradhana and usually, they are Akasha, Vayu, Agni Mahabhoota predominant. They help in Langhana as well as $\mathrm{Pa}$ chana.

Therefore, Nidana Parivarjana (elimination of the causative factors), Deepana (stimulative digestive fire), Pachana, Samsodhana (purification), Samsamana (pacifying) line of treatment can be adopted here:

\section{Nidana parivarjana}

All the factors which are responsible for the formation of disease mentioned earlier i.e., Kapha and Medo dhushtikara Ahara and Vihara should be avoided.

Deepana- Pachana

As there is both Jataragni and Dhatwagni mandya and formation of Ama in Samprapti, Agnideepana and Ama pachana helps in bringing back the Agni to normalcy and thus help in the proper transformation of Dhatus.

\section{Samshodhana}

Acharya Charaka has mentioned the fruitfulness of Shodhana Karma as by the administration of these therapies' diseases are cured and his normal health is restored.

Virechana Karma is the most suitable Shodhana Karma for liver disorders. It helps in bringing Dhatusthiratwa and Agnideepthi. It is also indicated in excessive Dosha accumulation and blockage of channels. Therefore, Mridu Virechana can be considered in the earlier stage of the disease.

Samshamana
Drugs which are having Tikta, Kashaya Rasa, Lekhana, Deepana and Pachana properties, which corrects the Agni and reduce Kapha, Meda and Ama are the choice of drugs for the management of NAFLD. Rasayana- Rasayana drugs corrects the structural deformity of the Dhatus and thus normalise the function and prevents any secondary disease. Free radical-mediated oxidative stress plays a major role in the formation of the disease. Therefore, the Rasayana drugs due to their antioxidant property play a good role in preventing the biological effect of free radicals.

PATHYA-APATHYA

Pathya Ahara-Madhudhaka, Mudga yusha, Ksheera, Ruksha Annam, Yava, Phalavarga

Pathya Vihara - Vyayamam, Jeerna ashanam Apathya Ahara - Excessive intake of Guru, Snigdha, Madhura, Pichila ahara, Navannam, Anupa and Varija mamsa, Goudika annam, milk and milk products. Apathya vihara - Ati nidra, Avyayama, Atibhojana, Shoka, Krodha, Bhaya.

\section{CONCLUSION}

Thus, Non-Alcoholic Fatty Liver Disease can be brought under the umbrella of Santarpanajanya Vyadhi. Considering NAFLD as a Santarpana janya vyadhi, Apatarpana Chikitsa should be adopted. It can be attained through Nidana Parivarjanam and Samprapti Vighatana. The treatment should aim at $A g$ nideepana, Amapachana, Srotoshodhana, Lekhana and Vatanulomana.

\section{REFERENCES}

1. Younossi ZM. Koenig AB. Abdelatif D, et al. Global epidemiology of nonalcoholic fatty liver disease Meta-analytic assessment of prevalence, incidence, and outcomes. Hepatology. 2016; 64:73-84. [PubMed]

2. Singh SP, Nayak S, Swain M, et al. Prevalence of nonalcoholic fatty liver disease in coastal eastern India: a preliminary ultrasonographic survey. Indian J Gastroenterol. 2004; 25:76-9

3. Calzadilla Bertot L, Adams LA. The Natural Course of Non-Alcoholic Fatty Liver Disease. Int J Mol Sci. 2016;17: pii: E774. [PMC free article] [PubMed] 
4. Aguilera-Méndez A. Nonalcoholic hepatic steatosis: a silent disease. Rev Med Inst Mex Seguro Soc. 2019 Mar 15;56(6):544-549. [PubMed]

5. Basaranoglu M, Neuschwander-Tetri BA. Nonalclic Fatty Liver Disease: Clinical Features and Pathogenesis. Gastroenterol Hepatol (N Y). 2006 Apr;2(4):282291. [PMC free article] [PubMed]

6. Basaranoglu M, Neuschwander-Tetri BA. Nonalcoholic Fatty Liver Disease: Clinical Features and Pathogenesis. Gastroenterol Hepatol (N Y). 2006 Apr;2(4):282-291. PMID: 28286458; PMCID: PMC5335683.

7. Neuschwander-Tetri BA Non-alcoholic fatty liver disease. BMC Med. 15, 45 (2017). [PMC free article] [PubMed]

8. Agnivesha.Santarpaniyam adhyayam. Sutrasthanm 23/1. In. Vaidya Acharya Jadavji Trikamji Acharya, editor. Charaka Samhita revised by Caraka and Drdhabala with Ayurveda - Dipika Commentary by Cakrapanidatta 2nd ed. Varanasi. Chowkhamba Publications 2014.p.395

9. Acharya Vagbhata. Ayushkamiyam Adhyayam. Sutrasthanm 1/19. In Bhisagacharya Harisastri Paradakara Vaidya, editor. Ashtanga Hrdaya, with the Sarvanga Sundara Commentary by Arunadatta and Ayurvedarasayana by Hemadri.9th ed. Varanasi: Chaukhambha Orientalia Publications;2005.

10. Acharya Vagbhata. Annaswaroopa vijnaneeyamAdhyayam. Sutrasthanm 6/58. In Bhisagacharya Harisastri Paradakara Vaidya, editor. Ashtanga Hrdaya, with the Sarvanga Sundara Commentary by Arunadatta and Ayurvedarasayana by Hemadri.9th ed. Varanasi: Chaukhambha Orientalia Publications;2005.

11. Acahrya Sushruta. Garbhinivyakarana sareera. Sareeerasthanam 4/13. In Vaidya Jadavji Trikamji Acarya, editor. Susruta Samhita with Nibandhasangraha Commentary by Sri Dalhanacharya and the Nyayacandrika Panjika of Sri Gayadasacharya.3 rd ed. Varanasi.Chowkamba Krishnadas Academy Publications, 2014.p.356

12. Acharya Vagbhata. Doshadivijnaniyam Adhyayam. Sutrasthanm 11/16-17. In Bhisagacharya Harisastri Paradakara Vaidya, editor. Ashtanga Hrdaya, with the Sarvanga Sundara Commentary by Arunadatta and Ayurvedarasayana by Hemadri.9th ed. Varanasi: Chaukhambha Orientalia Publications;2005.

13. Acharya Vagbhata. Maatrashitiyam Adhyayam. Sutrasthanm 8/16-17. In Bhisagacharya Harisastri Parada- kara Vaidya, editor. Ashtanga Hrdaya, with the Sarvanga Sundara Commentary by Arunadatta and Ayurvedarasayana by Hemadri.9th ed. Varanasi: Chaukhambha Orientalia Publications;2005.

14. Acharya Vagbhata. Maatrashitiyam Adhyayam. Sutrasthanm 8/16-17. In Bhisagacharya Harisastri Paradakara Vaidya, editor. Ashtanga Hrdaya, with the Sarvanga Sundara Commentary by Arunadatta and Ayurvedarasayana by Hemadri.9th ed. Varanasi: Chaukhambha Orientalia Publications;2005.

15. Agnivesha.Santarpaniyam adhyayam. Sutrasthanm 23/8. In. Vaidya Acharya Jadavji Trikamji Acharya, editor. Charaka Samhita revised by Caraka and Drdhabala with Ayurveda - Dipika Commentary by Cakrapanidatta 2nd ed. Varanasi. Chowkhamba Publications 2014.p.397.

16. Acharya Vagbhata. Maatrashitiyam Adhyayam. Sutrasthanm 8/20-22. In Bhisagacharya Harisastri Paradakara Vaidya, editor. Ashtanga Hrdaya, with the Sarvanga Sundara Commentary by Arunadatta and Ayurvedarasayana by Hemadri.9th ed. Varanasi: Chaukhambha Orientalia Publications;2005.

\section{Source of Support: Nil Conflict of Interest: None Declared}

How to cite this URL: Aparna Chandran et al: $\mathcal{A}$ Scientific Drug Review Onpunarnava Mandur. International Ayurvedic Medical Journal \{online\} 2021 \{cited November 2021\} Available from: http://www.iamj.in/posts/images/upload/2797_2801.pdf 